\title{
TECHNOLOGY AND QUALITY OF WHIPPED DESSERTS BASED ON MILK-PROTEIN CONCENTRATE
}

\author{
L. Deinychenko
}

National University of Food Technologies

\begin{tabular}{l} 
Key words: \\
Milk-protein concentrate \\
Buttermilk \\
Viburnum \\
Whipped dessert products \\
Dessert "Tiramisu” \\
\hline \multicolumn{1}{c}{ Article history: } \\
Received 12.01.2018 \\
Received in revised form \\
30.01.2018 \\
Accepted 07.02.2018 \\
\hline
\end{tabular}

Corresponding author:

V. Gnitsevych

E-mail:

npnuht@ukr.net

\begin{abstract}
The article provides the technology of making and studies the quality of the dessert "Protein Tiramisu", which is made on the basis of milk-protein concentrate, a new type of non-traditional protein-containing raw material, which is characterized by an increased content of all essential amino acids, a better balance of the amino acid composition and optimal correlation of essential amino acids.

To solve the problem, dessert "Tiramisu" based on cottage cheese was taken as basis and control. To obtain the dessert "Protein Tiramisu", the egg yolks were churned with sugar, a part of the concentrate and proteins whipped with the remaining part of the concentrate were added. The resulting blend was gently mixed, cooled and used as a cream for dessert preparation.

The chemical composition of the obtained product was determined according to the methods given in the current normative documentation of Ukraine. It is determined that the developed dessert is characterized by a significant increase in protein content, a slight increase in fat content and a significant reduction in the content of carbohydrates. The content of mineral substances and ascorbic acid is also significantly increased.

An analysis of the integral score of the product was made relying on the providing of $10 \%$ of the daily energy needs of the person belonging to the workers of the third group of labor intensity. According to the obtained data, the developed product provides a daily need in protein substances by almost $30 \%$, for mineral substances - by $25 \%$ on the average. The constructed organoleptic profiles indicated improving of consistency, smell and taste of the developed product in comparison with control.

The data presented in the article indicate the possibility of using of milk-protein concentrate based on buttermilk, obtained with the use of viburnum puree as coagulant, for the production of whipped dessert products in order to increase its quality and expand the range of whipped desserts in the restaurants.
\end{abstract}

DOI: $10.24263 / 2225-2924-2018-24-1-24$ 


\title{
ТЕХНОЛОГІЯ ТА ЯКІСТЬ ЗБИТИХ ДЕСЕРТІВ НА ОСНОВІ МОЛОЧНО-БІЛКОВОГО КОНЦЕНТРАТУ
}

\author{
Л.Г. Дейниченко \\ Наиіональний університет харчових технологій
}

У статті запропоновано технологію виробництва та досліджено якість десерту «Тирамісу білковий», який виготовляється на основі молочно-білкового концентрату, що є новим видом нетрадиційної білоквмісної сировини $i$ характеризується підвищеним вмістом усіх незамінних амінокислот, кращою збалансованістю амінокислотного складу та оптимальним співвідношенням есенціальних амінокислот.

Для вирішення поставленого завдання за основу та контроль було взято рецептуру десерту «Тирамісу» із сиру кисломолочного. Для отримання десерту «Тирамісу білковий» яєчні жовтки збивали з иукром, додавали частину концентрату та білки, збиті у піну разом із конщентратом, що залишився. Отриману суміш обережно перемішували, охолоджували та використовували як крем для приготування десерту.

Хімічний склад отриманого продукту визначено за методиками, наведеними у чинній нормативній документації Украӥни. Визначено, щьо розроблений десерт характеризується суттєвим підвищенням вмісту білків, незначним підвищенням вмісту жиру та вагомим зниженням вмісту вуглеводів. Також значно зростають вміст мінеральних речовин та аскорбінової кислоти.

Аналіз інтегрального скору продукту проводили у розрахунку на забезпечення 10\% добової потреби в енергії людини, щяо належить до робітників III групи інтенсивності праці. Згідно з отриманими даними розроблений продукт забезпечує добову потребу у білкових речовинах майже на $30 \%$, у мінеральних речовинах - у середньому на 25\%. Побудовані органолептичні профілі вказують на покращення консистениії, запаху та смаку розробленого продукту порівняно з контролем.

Дані, наведені у статті, свідчать про можливість використання молочно-білкового концентрату зі сколотин, отриманого з використанням пюре калини як коагулянту для виробництва збитої десертної продукиії з метою підвищення ї̈ якості та розширення асортименту у закладах ресторанного господарства.

Ключові слова: молочно-білковий концентрат, сколотини, калина, збита десертна продукиія, десерт «Тирамісу».

Постановка проблеми. Сьогодні ефективним способом забезпечення людства необхідними для життя і розвитку нутрієнтами, особливо на фоні дефіциту білкових речовин, що стрімко розвивається у світі [1], є споживання багатих на білок продуктів. Цінною сировиною для їх виробництва $\epsilon$ білкові концентрати та копреципітати, отримані з вторинних продуктів молочної 
промисловості, зокрема сколотин. Такі концентрати, крім високого вмісту білкових речовин, мають багатий вуглеводний і мінеральний склад, низький вміст жиру, а також поліпшені органолептичні та функціонально-технологічні характеристики [2].

Молочно-білкові концентрати зі сколотин, отримувані з використанням пюре калини (МБКК) [3], є новим видом нетрадиційної білоквмісної сировини, що характеризується низкою переваг порівняно з традиційними продуктами, зокрема кисломолочним сиром. Так, якщо порівняти з останнім, отримувані концентрати характеризуються підвищеним вмістом усіх незамінних амінокислот, кращою збалансованістю амінокислотного складу, оптимальним співвідношенням таких есенціальних амінокислот, як триптофан, метіонін i лізин. Крім того, за рахунок використання у технології дикорослої ягідної сировини МБКК мають високу інтегральну антиоксидантну активність, що свідчить про можливість ї використання для виробництва продуктів функціонального призначення.

Основне призначення розроблених концентратів полягає у їх використанні в закладах ресторанного господарства та домашньому господарстві для виробництва напівфабрикатів і кулінарних виробів на молочно-білковій основі. При цьому слід враховувати, що під час розробки рецептур нових страв $\mathrm{i}$ виробів важливе значення надається врахуванню ряду вимог, що передбачають отримання продуктів 3 високими харчовою та біологічною цінністю, добрими смаковими якостями, здатних задовольнити санітарно-гігієнічні норми обробки, зберігання й транспортування.

Крім того, до розроблюваних продуктів і напівфабрикатів висуваються специфічні вимоги, основними з яких $\epsilon$ наявність необхідної консистенції $\mathrm{i}$ здатність не змінювати структурні характеристики при виготовленні і зберіганні. Для МБКК характерними рисами є гладкість і зернистість молекул, слабкі асоціативні зв'язки між ними, а також наявність виражених піноутворюючих і стабілізуючих властивостей. У зв'язку з цим, грунтуючись на даних, отриманих під час проведення експериментів та 3 урахуванням відомостей, що містяться в науково-технічній літературі, можна стверджувати, що раціональним $є$ використання отриманих концентратів для виробництва збитої десертної продукції.

Аналіз останніх досліджень і публікацій. Доцільність використання молочно-білкових концентратів (МБК) у різних галузях харчової промисловості для зниження собівартості продукції і поліпшення якості готових виробів на сьогодні $\epsilon$ доведеним фактом. Так, широко відомо про використання таких добавок при виробництві ковбасних, молочних, хлібобулочних і кондитерських виробів.

Сьогодні відомо про розробку ряду технологій, що мають на меті отримання продукції з дисперсною структурою, заснованих на реалізації функціонально-технологічних властивостей компонентів молочної та рослинної сировини. Зокрема, вченими Національного університету харчових технологій [4] було розроблено пастоподібну молочно-білкову основу для десертів, яку отримують шляхом нормалізації та пастеризації суміші знежиреного 
молока та сколотин у співвідношенні 5:3, осадження білків кислою сироваткою $з$ температурою $68 \ldots 72^{\circ} \mathrm{C}$, витримки і охолодження до $30 \ldots 50^{\circ} \mathrm{C}$, самопресуванням до масової частки вологи $68 . .72 \%$.

Дослідниками Донецького національного університету економіки і торгівлі ім. М.І. Туган-Барановського розроблено білково-рослинні основи для збитих солодких страв «Кизилова», «Тернова», «Кизилово-тернова» [5], що виготовляються 3 концентратів на основі знежиреного молока, пюре з плодів дикорослих кизилу, терену або їх суміші, цукру, лимонної кислоти та яблучного пектину. Отримувані основи мають високу та стабільну піноутворюючу здатність і суттєво впливають на собівартість готових страв, зменшуючи енерговитрати, скорочуючи кількість і тривалість технологічних операцій та підвищуючи ефективність технологічного процесу.

Відомо також про патентування технології збитого кисломолочного десерту на основі молочно-білкового концентрату зі сколотин, смакового наповнювача (какао-порошок, екстракт кави, фруктові сиропи та пюре) та ксампану [6].

Аналізуючи наведені дані, можна зробити висновок, що сьогодні процес розробки асортименту страв і виробів на основі МБК зазнає активного розвитку. Проте технології виробництва страв і виробів на основі МБК, орієнтовані на використання у закладах ресторанного господарства, майже відсутні. Тому доцільною є їх розробка для розширення асортименту продукції ЗРГ, підвищення іiі харчової та біологічної цінності, а також скорочення часу та енерговитрат на ії̈ виробництво.

Метою статті $\epsilon$ розробка технології десерту «Тирамісу білковий» на основі МБКК, а також визначення якості отриманого продукту.

Матеріали і методи. У процесі дослідження використано методи аналізу й синтезу, порівняння, системного підходу.

Загальний хімічний склад отриманого продукту визначено за стандартними методиками [7-10]. Інтегральний скор розраховано на масу продукту, що відповідає 330 ккал, тобто 10\% добової потреби в енергії людини, що належить до робітників III групи інтенсивності праці [11].

Органолептичну оцінку якості продукту здійснено методом профільного аналізу (кількісним). Профілі якості будували за допомогою обчислювальної програми MS Excel.

Викладення основних результатів дослідження. Для вирішення поставленого завдання за основу та контроль було взято рецептуру десерту «Тирамісу» на основі сиру кисломолочного. В новій технології передбачено використання МБКК, що має на меті не тільки підвищення хімічного та біологічного складу готових виробів, а й зростання піно- і структуроутворювальних властивостей розроблюваних продуктів.

Для отримання 1 кг десерту «Тирамісу білковий» на основі МБКК яєчні жовтки (3 шт) збивають 3 цукром (70 г) до білого кольору, додають $2 / 3$ концентрату (32 г) та обережно перемішують лопаткою до однорідності маси. Білки збивають до густої піни, поступово додаючи концентрат, що залишився (18 г), і обережно додають до основної маси. Отриману суміш обе- 
режно перемішують до однорідності і залишають у холодильнику на $25 .$. 30 хвилин.

Каву (12 г) заливають 200 мл кип'яченої води та ретельно розмішують. В утворений напій додають коньяк (40 мл) та переливають у глибоку тарілку. Охолоджену білкову масу переносять у кулінарний пакет. Десерт викладають у креманки, чергуючи білковий крем і печиво «Савоярді» (200 г), змочене у каві з коньяком. Поверхню десерту посипають какао-порошком (20 г) і залишають у холодильнику на 5 годин. Технологічну схему десерту наведено на рис. 1.

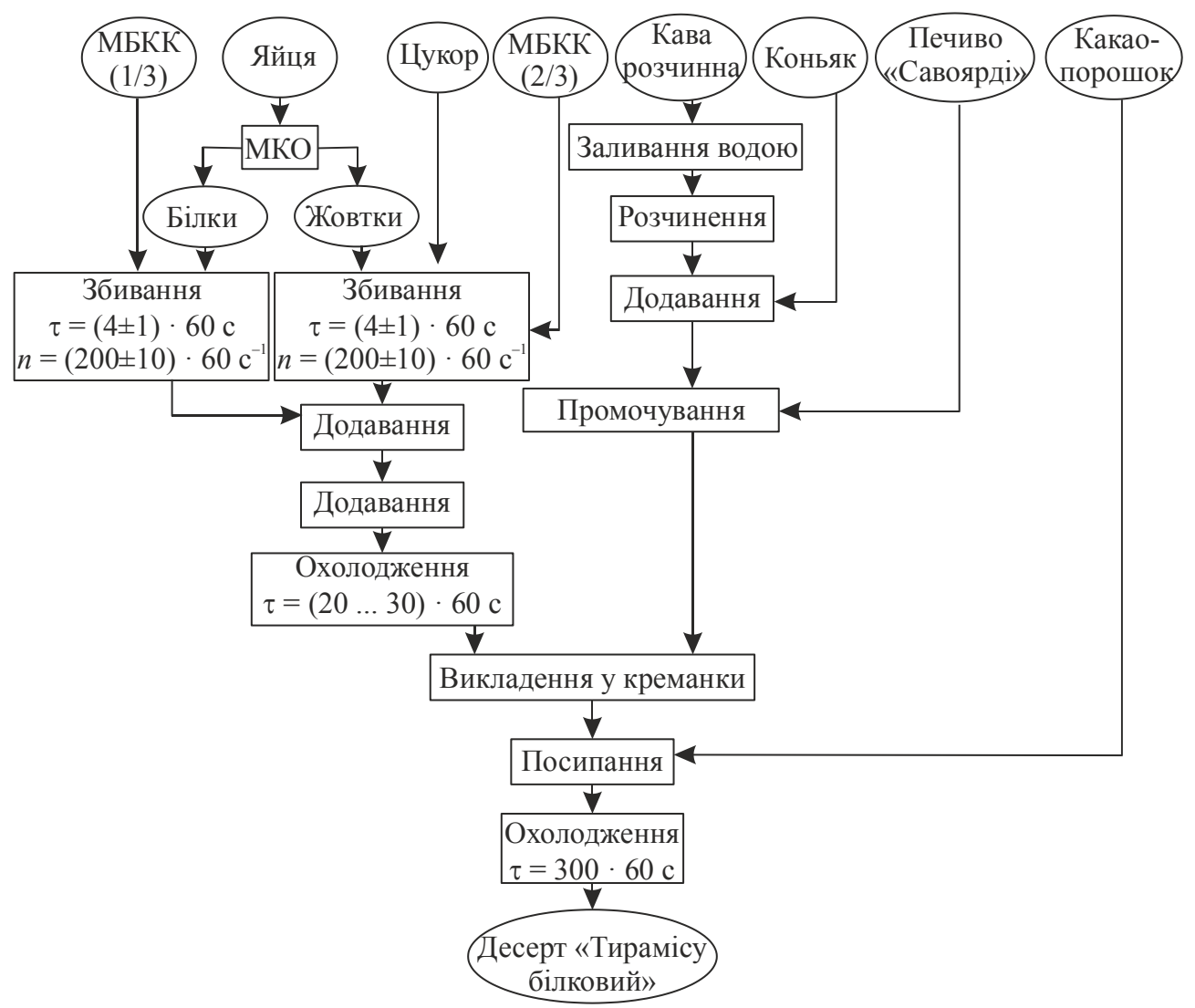

Рис. 1. Технологічна схема десерту «Тирамісу білковий»

Для визначення якості отримуваного продукту було розраховано його хімічний склад, інтегральний скор та побудовано органолептичні профілі якості. Хімічний склад продукту наведено в табл. 1.

Таблиия 1. Хімічний склад розробленого десерту порівняно з контролем

\begin{tabular}{|c|c|c|}
\hline \multirow{2}{*}{ Харчові речовини } & \multicolumn{2}{|c|}{ Вміст у 100 г } \\
\cline { 2 - 3 } & Десерт «Тирамісу» (контроль) & Десерт «Тирамісу білковий» \\
\hline 1 & 2 & 3 \\
\hline Білки, г & $13,2 \pm 0,6$ & $17,0 \pm 0,9$ \\
\hline
\end{tabular}




\begin{tabular}{|c|c|c|}
\hline & & Продовження табл. 1 \\
\hline 1 & 2 & 3 \\
\hline Жири, г & $7,4 \pm 0,4$ & $7,8 \pm 0,4$ \\
\hline Вуглеводи, г & $28,9 \pm 1,5$ & $18,4 \pm 0,9$ \\
\hline \multicolumn{3}{|c|}{ Мінеральні речовини, мг } \\
\hline Калій (К) & $146 \pm 7$ & $308 \pm 15$ \\
\hline Кальцій (Ca) & $115 \pm 6$ & $232 \pm 12$ \\
\hline Натрій (Na) & $154 \pm 8$ & $246 \pm 12$ \\
\hline Магній (Mg) & $22 \pm 1$ & $70 \pm 4$ \\
\hline Залізо $(\mathrm{Fe})$ & $1,6 \pm 0,1$ & $1,5 \pm 0,1$ \\
\hline Фосфор (P) & $180 \pm 9$ & $237 \pm 12$ \\
\hline \multicolumn{3}{|c|}{ Вітаміни, мг } \\
\hline Вітамін C & $0,29 \pm 0,01$ & $0,64 \pm 0,03$ \\
\hline Вітамін $\mathrm{B}_{1}$ & $0,10 \pm 0,01$ & $0,10 \pm 0,01$ \\
\hline Вітамін $\mathrm{B}_{2}$ & $0,29 \pm 0,01$ & $0,24 \pm 0,01$ \\
\hline Вітамін РP & $0,79 \pm 0,04$ & $0,82 \pm 0,04$ \\
\hline
\end{tabular}

Як можна побачити 3 даних, представлених у табл. 1, розроблений десерт характеризується суттєвим підвищенням вмісту білків - на 29\% (порівнюючи 3 контролем). Незначне підвищення вмісту жирів (на 0,4 г) спостерігається внаслідок використання МБКК, жирність якого складає 1,91 г/100 г проти 0,6 г/100 г для сиру кисломолочного нежирного. Характерним також $є$ зменшення вмісту вуглеводів (на 10,5 г), що є наслідком значного зниження вмісту цукру.

Мінеральний склад білкового десерту також покращується, порівняючи 3 контролем. Зокрема, вміст Са зростає у 2 рази, $\mathrm{K}$ - у 2,1 раза, $\mathrm{Na}-1,6$ раза, $\mathrm{P}$ - у 1,3 раза, $\mathrm{Mg}$ - у 3,2 раза. Серед вітамінів значним $є$ підвищення вмісту аскорбінової кислоти (у 2,2 раза).

Для визначення ступеня задоволення добової потреби організму в основних харчових речовинах було розраховано інтегральний скор розробленого десерту (табл. 2).

Таблиия 2. Інтегральний скор розробленого десерту порівняно 3 контролем

\begin{tabular}{|c|c|c|c|c|c|}
\hline \multirow[t]{2}{*}{ Харчові речовини } & \multirow{2}{*}{$\begin{array}{l}\text { Добова } \\
\text { потреба }\end{array}$} & \multicolumn{2}{|c|}{ «Тирамісу» (контроль) } & \multicolumn{2}{|c|}{$\begin{array}{c}\text { Десерт «Тирамісу } \\
\text { білковий» }\end{array}$} \\
\hline & & $137 \Gamma$ & $\mathrm{C} 3, \%$ & $152 \Gamma$ & $\mathrm{C} 3, \%$ \\
\hline 1 & 2 & 3 & 4 & 5 & 6 \\
\hline Білки, г & 91 & 18,04 & 20 & 25,77 & 28 \\
\hline Жири, г & 92 & 10,11 & 11 & 11,82 & 13 \\
\hline Вуглеводи, г & 528 & 39,50 & 7 & 27,89 & 5 \\
\hline \multicolumn{6}{|c|}{ Мінеральні речовини, мг } \\
\hline Калій (К) & 2500 & 146 & 6 & 467 & 19 \\
\hline Кальцій (Са) & 1200 & 115 & 10 & 352 & 29 \\
\hline Натрій (Na) & 4000 & 154 & 4 & 373 & 9 \\
\hline Магній (Mg) & 400 & 22 & 6 & 106 & 27 \\
\hline Залізо (Fe) & 15 & 1,6 & 11 & 2,3 & 15 \\
\hline Фосфор (P) & 1200 & 180 & 15 & 359 & 30 \\
\hline \multicolumn{6}{|c|}{ Вітаміни, мг } \\
\hline Вітамін C & 80 & 0,29 & 0 & 0,97 & 1 \\
\hline
\end{tabular}




\begin{tabular}{|c|c|c|c|c|c|}
\hline \multicolumn{1}{|c|}{ Продовження табл. 2 } \\
\hline Вітамін $\mathrm{B}_{1}$ & 2 & 3 & 4 & 5 & 6 \\
\hline Вітамін $\mathrm{B}_{2}$ & 1,6 & 0,10 & 6 & 0,15 & 9 \\
\hline Вітамін РP & 2,0 & 0,29 & 15 & 0,36 & 18 \\
\hline
\end{tabular}

Згідно $з$ отриманими даними розроблений десерт задовольняє потребу у білкових речовинах, забезпечуючи ії на $28 \%$. Також значним є задоволення потреби у мінеральних речовинах. Так, воно становить 19\% для калію, $29 \%$ для кальцію, 27\% для магнію, 30\% - для фосфору, 15\% - для заліза. 3 вітамінів слід відмітити рибофлавін — потреба у ньому задовольняється на $18 \%$.

Органолептичну оцінку розробленого продукту було визначено після проведення дегустації, в ході якої провідні фахівці галузі відзначили високі органолептичні показники представленого десерту та рекомендували його до впровадження в закладах ресторанного господарства. На основі отриманих оцінок було побудовано органолептичні профілі, представлені на рис. 2.

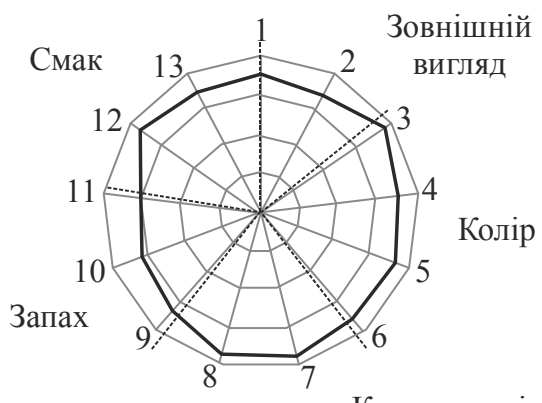

a) $S=4,88$

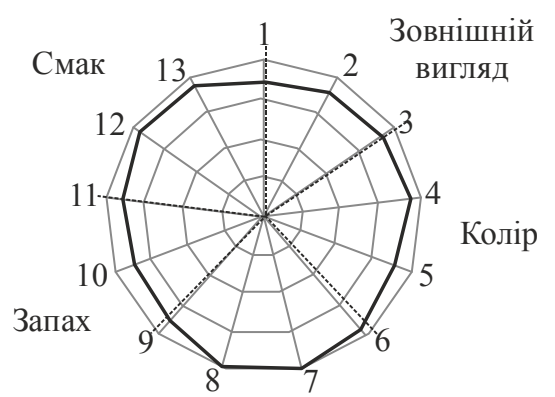

Консистенція

б) $S=4,91$

Рис. 2. Органолептичний профіль десерту «Тирамісу білковий» (б) порівняно $з$ контролем (а)

На рис. 2 можна побачити, що розроблений десерт порівняно з контролем має кращі консистенцію, запах і смак. Також визначено, що загальна органолептична оцінка розробленого продукту складає 4,91 проти 4,88 для контролю.

Враховуючи високу антиоксидантну активність і збалансований амінокислотний склад МБКК, слід зазначити, що розроблений десерт, крім поліпшених споживних властивостей, має подовжений термін придатності та виражені радіопротекторні властивості.

\section{Висновки}

Отриманий десерт «Тирамісу білковий» є перспективним продуктом, що характеризується високою харчовою та біологічною цінністю, високим рівнем забезпечення добової потреби у необхідних для організму людини нутрієнтах, а також гарними органолептичними властивостями. Виробництво розробленого продукту у закладах ресторанного господарства дасть змогу розширити асортимент білкових десертів і підвищити попит на десертну продукцію внаслідок зниження іiї вартості. 


\section{Література}

1. Tilly J. Opportunities to Improve Nutrition for Older Adults and Reduce Risk of Poor Health Outcomes. Administration for Community Living or the U.S. Department of Health and Human Services [Електронний ресурс]. - Режим доступу: http://nutritionandaging.org/wpcontent/uploads/2017/03/Malnutrition-Issue-Brief-final-3-2017.pdf.

2. Гніцевич В.А. Інновації у виробництві молочно-білкових копреципітатів / В.А. Гніцевич, Л. Г. Дейниченко // Туристичний, готельний і ресторанний бізнес: інновації та тренди [Текст] : тези доп. міжнар. наук.-практ. конф. (квіт. 2016) / відп. ред. А.А. Мазаракі. — Київ : Київ. нац. торг.-екон. ун-т, 2016. - 362 с.

3. Гнічевич B.A. Технологія та біологічна цінність молочно-білкових копреципітатів / В.А. Гніцевич, Т.І. Юдіна, Л.Г. Дейниченко // Товари і ринки. — 2016. — № 2(22). C. $148-158$.

4. Пат. 34115 Україна, МПК 6 А 23 С 23/00. Спосіб отримання молочно-білкової основи для десертів / В.О. Ромоданова, Г.Б. Федорова, Н.О Пененко та ін. — №99063074 ; заявл. 03.06.99; опубл. 15.02.01, Бюл. № $1 .-4$ c.

5. Пат. 20069 Україна, МПК(2006) А23С 23/00, А23С 9/152. Спосіб одержання білково-рослинної основи для збитих солодких страв / Р.П. Нікіфоров, В.А. Гніцевич, Т.Ф. Коршунова. — № 200606861 ; Заявл. 19.06.06 ; Опубл. 15.01.07, Бюл. № 1. - 2 с.

6. Пат. 71825 Україна, МПК 7 А 23 С 23/00. Спосіб виробництва збитого кисломолочного десерту / Г.В. Дейниченко, Т.І. Юдіна, О.В. Самохвалова, В.М. Ветров. № 20031212920 ; заявл. 29.12.03 ; опубл. 15.12.04, Бюл. № 12. - 3 с.

7. ДСТУ ISO 6496:2005. Корми для тварин. Визначення вмісту вологи та інших летких речовин [Текст]. - Введ. 2007-07-01. — Київ : Держспоживстандарт України, 2006. - 11 с.

8. ДСТУ ISO 5984:2004 Корми для тварин. Визначення вмісту сирої золи [Текст]. Введ. 2006-01-01. — Київ : Держспоживстандарт України, 2006. - 8 с.

9. ДСТУ ISO 6492:2003 Корми для тварин. Визначення вмісту жиру [Текст]. - Введ. 2005-07-01. - Київ : Держспоживстандарт України, 2005. - 12 с.

10. ДСТУ ISO 5983:2003 Корми для тварин. Визначення вмісту азоту і обчислення вмісту сирого білка методом К'єльдаля [Текст]. — Введ. 2005-07-01. — Київ : Держспоживстандарт України, 2007. - 12 с.

11. Про затвердження Норм фізіологічних потреб населення України в основних харчових речовинах та енергії: норми від 18.11.1999 № 272 [Електронний ресурс] // MO3 України [Електронний ресурс]. — Режим доступу : http://zakon2.rada.gov.ua. — Назва 3 екрана. 